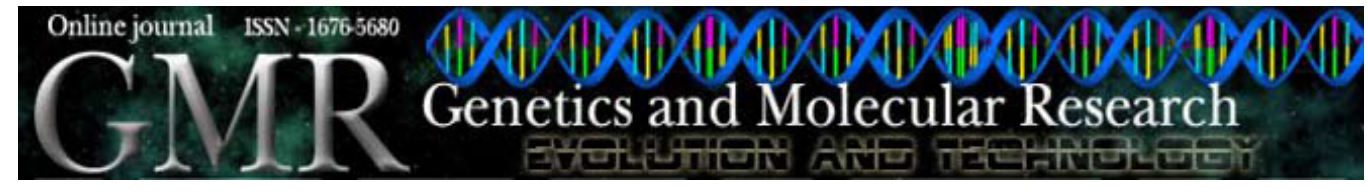

\title{
Interaction and behavior of virgin and physogastric queens in three Meliponini species (Hymenoptera, Apidae)
}

\author{
F.H. Nogueira-Ferreira ${ }^{1}$, E.V. Silva-Matos ${ }^{2}$ and R. Zucchi ${ }^{2}$ \\ ${ }^{1}$ Instituto de Biologia, Universidade Federal de Uberlândia, \\ Uberlândia, MG, Brasil \\ ${ }^{2}$ Departamento de Biologia, Faculdade de Filosofia, \\ Ciências e Letras de Ribeirão Preto, \\ Universidade de São Paulo, Ribeirão Preto, SP, Brasil \\ Corresponding author: F.H. Nogueira-Ferreira \\ E-mail: ferferre@inbio.ufu.br
}

Genet. Mol. Res. 8 (2): 703-708 (2009)

Received December 12, 2008

Accepted January 26, 2009

Published June 16, 2009

\begin{abstract}
We studied the behavior of virgin queens of the stingless bee species Schwarziana quadripunctata, Paratrigona lineata and Tetragona clavipes, investigating internal nest activities, including the cell provisioning and oviposition process. We made direct observation of queen behavior, with the aid of video filming. Forty-four virgin queens of $S$. quadripunctata were observed; one was larger and more attractive than the others. Miniature queens were more abundant than normal-size queens; both were found in prison chambers. Agonistic behavior between virgin and physogastric queens of $P$. lineata was observed during attempts at queen supersedure. After the disappearance of the physogastric queen and the appearance of a virgin queen in T. clavipes nests, the brood cells were sealed with pollen alone, but no egg. In all three species, the presence of one or more virgin queens appeared to make the colonies
\end{abstract}


nervous, even though constant production of virgin queens is vital to the survival of the colony and is part of the colony cycle in these bees.

Key words: Meliponinae; Colony homeostasis; Behavior; Virgin queens; Cell provisioning and oviposition process; Interactions

\section{INTRODUCTION}

In the eusocial bees, workers are constantly produced in the colony under normal conditions. Generally, the production of queens is limited, though in the Meliponinae, they are produced all year. The number of queens produced depends on the species, colony conditions, the amount of food available, the physiological state of the physogastric queen, and the reproductive cycle of the colony. Continuous production of queens apparently minimizes the risk of irreversible loss of the queen (Engels and Imperatriz-Fonseca, 1990).

In Melipona spp, numerous queens are produced simultaneously, and they can live together for a variable period of time, depending on colony conditions. Some virgin queens are eliminated, while others that apparently are more attractive, survive; these are courted actively by the workers. In the genus Trigona, the number of emerging queens is smaller than in the Melipona; in the former, more than one virgin queen in the nest is less frequent (Engels and Imperatriz-Fonseca, 1990).

In some stingless bee species, normal queens emerge from royal cells and small queens emerge from cells similar to those that produce workers. This has been reported for colonies of Cephalotrigona capitata (Ihering, 1903), Plebeia juliani (Juliani, 1962; Imperatriz-Fonseca and Zuchi, 1995), Plebeia remota (Ribeiro et al., 2006), Nannotrigona testaceicornis (Imperatriz-Fonseca et al., 1997) and Schwarziana quadripunctata (Camargo, 1974; Imperatriz-Fonseca and Darakjian, 1993; Nogueira-Ferreira et al., 2000; Ribeiro and Alves, 2001; Wenseleers et al., 2005). Ribeiro et al. (2006) revised the existing information about production of miniature queens; they hypothesized that miniature queens are females who selfishly evade an intended worker's fate.

During the swarming process or during queen supersedure, male aggregations in the proximities of the nest have been observed for many species of Meliponini, including Trigona fulviventris, Scaura, Nannotrigona (Michener, 1946), Tetragonisca angustula (Michener, 1946; Nogueira-Ferreira and Soares, 1998) and Scaptotrigona postica (Kerr et al., 1962). These males are waiting for the nuptial flight of the queen; after she is mated, few such males remain (Kerr et al., 1962). On the other hand, in Melipona spp male aggregation behavior is different. Sommeijer and de Bruijn (1995) found a congregation of males of Melipona favosa far from the entrance of the nest. In this case, the virgin queens went to that area, different what has been observed in other Meliponini groups.

We examined the behavior of virgin queens in three species of stingless bees, investigating the behavioral alterations in the development of the internal nest activities, mainly related to the cell provisioning and oviposition process (Sakagami and Zucchi, 1967).

\section{MATERIAL AND METHODS}

Virgin queens of Schwarziana quadripunctata, Paratrigona lineata and Tetragona 
clavipes were studied. Colonies were transferred to wooden boxes, covered with glass and maintained in the laboratory. These nests communicated with the exterior through a plastic tube, and they were studied through direct observations and/or videos of worker and queen behavior.

After transferring a nest of S. quadripunctata, from the city of Cunha, SP, in March of 1994, 44 queens were collected and marked. Many of them were confined by the workers in prison chambers. Whenever possible, a glass slide was placed over the prison chamber, which allowed observation of the interactions between the virgin queen and the workers.

The nest of P. lineata was collected from an Atta nest on the University of São Paulo campus, in Ribeirão Preto, at a depth of 1.90 m, on April 22, 1991.

The nest of T. clavipes was collected from Cajuru, SP, from a cavity of Cedrela sp. It was $95 \mathrm{~cm}$ long and 20 to $25 \mathrm{~cm}$ in diameter. There were 38 cells in different stages of construction (14 were in the collar, that were ready), distributed in two horizontal combs. There were also three combs with larvae in the feeding phase and 13 older combs (containing prepupae, pupae and numerous royal cells). A process of queen supersedure was observed from September 17 to October 7, 1993.

\section{RESULTS}

\section{Behavior of virgin queens of Schwarziana quadripunctata}

During one month, 44 queens (Table 1) of a nest of $S$. quadripunctata were collected and marked; one was a normal queen and the others were miniature queens. The queens that emerged were not attractive to the workers and they had little pigmentation. In this phase, they became less active, stationary on the comb. As the virgin queens became older, there was an increase in pigmentation of the body, together with an increase in attractiveness to the workers.

As the virgin queens became more attractive, they were courted on the comb or on the cerumen layers surrounding the comb. At this time, some virgin queens were seen manipulating the cerumen in the area of the involucrum, beginning the construction of prison chambers. At that phase of the colony cycle, the cell provisioning and oviposition process differed from what is seen in queenright colonies; the number of provisioned cells was reduced (Table 1). For several days, workers left the nest, transporting wax in their corbiculae, a behavior that is not seen in queenright colonies. Sometimes there was an encounter between the physogastric queen and the virgin queen; aggressive behavior between them was not observed (Table 1), though there was buccal contact.

Prison chambers, which had a prolonged and irregular format, were built in the area of the involucrum, very close to the combs. These chambers contained one to five virgin queens, sometimes accompanied by one or two workers (Table 1). Dominance behavior was not observed among the queens that occupied the same chamber.

Increasing attractiveness of the virgin queen seemed to provoke her imprisonment. Sometimes, the prison chamber was open, and the queen stayed alone inside the chamber. In other cases, when we opened chambers that were closed, the queens quickly escaped.

One of the virgin queens was visibly larger than the others, and it was well pigmented. This queen became very agitated, while inside the prison chamber. She was accompanied by up to four workers, fanning their wings and walking quickly. Sometimes, she moved, rotating 
her body abruptly, hitting the workers with her abdomen. When this virgin queen was inside the chamber it was common for workers to make buccal contact with her, through a lateral hole. The day after this behavior was observed, we saw this queen executing small flights inside the colony, becoming very agitated.

After emergence of the attractive virgin queen, brood cell construction was interrupted, and some cells were destroyed. However, when the physogastric queen visited the comb it was usually courted by the workers, as in queenright colonies. During that phase, we saw male aggregations on the outside of the nest (Table 1).

Two days after being marked, the big virgin queen was found dead; her thorax was being carried by a worker. Other virgin queens were seen, gathered in an area close to the food pots. Up to 5 virgin queens were found in these "refuges".

\section{Agonistic interaction involving the virgin queen and the physogastric queen in Paratrigona lineata}

During video-recording, a curious and hitherto unknown event was seen. As soon as the physogastric queen started inspecting a provisioned cell, she was suddenly mounted by the fully pigmented virgin queen during less than $2 \mathrm{~s}$ (Table 1). The virgin queen's abdomen was positioned over the head and thorax of the physogastric queen.

This aggressive behavior against the physogastric queen provoked the interruption of the oviposition process (Table 1). The physogastric queen retreated quickly and moved to the side of the cell where she had laid previously. The workers quickly surrounded her and began to lick her. She was completely surrounded by workers. After the aggression, the virgin queen went to an area of the involucrum near where the physogastric queen is. We observed that the queen supersedure did not occur during the next days.

\section{Queen supersedure in Tetragona clavipes}

After installation of the nest of T. clavipes in the laboratory, we observed some males at the entrance of the colony (Table 1). After four days, the physogastric queen disappeared from the colony; on the same day, an attractive virgin queen was seen. The number of males on the outside of the nest, increased considerably.

While the physogastric queen was still in the colony, after the virgin queen was observed, the physogastric queen was not seen laying eggs. However, cells were sealed in an irregular manner (Table 1). During the day previous to the disappearance of the physogastric queen, she visited the comb 12 times for $2 \mathrm{~h}$; however, she stayed more than $90 \%$ of the time off the comb. In the last days that physogastric queen was present in the colony, we saw that the behaviors that compose the cell provisioning and oviposition process were not normal, they did not develop according to a fixed sequence of behaviors (Sakagami and Zucchi, 1967).

Six days after the attractive virgin queen was first observed, she started to inspect and to visit cells under construction. Her abdomen slightly more distended, indicating the possibility of her having mated. On that day, the virgin queen ate a trophic egg that a worker had laid in a provisioned brood cell. The workers did not sealed the cell. This was repeated twice more; the third time, the workers sealed the cell containing the food.

The new queen laid for the first time eight days after having arrived in the colony. Her be- 
havior and that of the provisioning workers was followed for several days, during which few cells were provisioned and the normal sequence of behaviors was not completely established (Table 1).

\begin{tabular}{|c|c|c|c|c|c|}
\hline Bee species & $\begin{array}{l}\text { Number of virgin } \\
\text { queens present } \\
\text { in the nest }\end{array}$ & $\begin{array}{l}\text { Interaction between } \\
\text { physogastric } \\
\text { and virgin queens }\end{array}$ & $\begin{array}{l}\text { Cell provisioning } \\
\text { and oviposition } \\
\text { process }\end{array}$ & $\begin{array}{c}\text { Male } \\
\text { aggregations }\end{array}$ & Prison chambers \\
\hline $\begin{array}{l}\text { Schwarziana } \\
\text { quadripunctata }\end{array}$ & $\begin{array}{l}44 \text { (1 normal and } \\
1 \text { miniature) }\end{array}$ & $\begin{array}{l}\text { Interactions not } \\
\text { aggressive }\end{array}$ & $\begin{array}{l}\text { Abnormal, number } \\
\text { of cells laid decreased }\end{array}$ & Present & $\begin{array}{l}1-5 \text { virgin queens } \\
\text { and } 1-2 \text { workers }\end{array}$ \\
\hline Paratrigona lineata & 1 & $\begin{array}{l}\text { Agonistic } \\
\text { interactions }\end{array}$ & Interrupted & No observed & Absent \\
\hline Tetragona clavipes & $\begin{array}{l}2 \text { (1 atractive and } \\
\text { the other not) }\end{array}$ & No interaction & $\begin{array}{l}\text { Abnormal, pollen } \\
\text { deposited directly } \\
\text { in the cells }\end{array}$ & Present & Absent \\
\hline
\end{tabular}

\section{DISCUSSION}

Schwarziana quadripunctata virgin queens are of two sizes, though both types are treated by the workers as queens. The miniature queens can lay fertile eggs; though their eggs are smaller than those of the normal-sized queens they can head colonies (Castilho-Hyodo, 2001). However, they lay fewer eggs than normal-size queens (Ribeiro and Alves, 2001; Wenseleers et al., 2005; Ribeiro et al., 2006).

The increase in attractiveness of the virgin queen seems to provoke her imprisonment, probably because of her sexual maturity. In S. quadripunctata, some virgin queens were seen manipulating the wax in the area of the involucrum, beginning the construction of prison chambers. Abdalla et al. (2005) found well-developed wax glands in both workers and queens. The queens produce the wax used for the construction of the cerumen prison chambers.

The colony of $S$. quadripunctata was starting a swarming process, because workers flew out with wax in their corbiculae, which is characteristic of various species of stingless bees (Imperatriz-Fonseca, 1990; Nogueira-Ferreira and Soares, 1998). Though S. quadripunctata is a species in which queens are constantly produced (44 virgin queens in the colony we studied), they normally do not have more than two or three queens. The lack of dominance among virgin queens gathered on the involucrum in "refuges", near food pots, was also observed by Kleinert and Imperatriz-Fonseca (1994), for Melipona marginata.

The presence of attractive virgin queens in the colony interferes in the behavioral sequences of the cell provisioning and oviposition process. However, the production of extra queens is vital to the survival of the colony and it is part of the colony cycle.

\section{ACKNOWLEDGMENTS}

This paper is dedicated to Prof. Dr. Warwick Estevam Kerr. We thank Sidnei Mateus (FFCLRP-USP) for his invaluable help and technical support. We also thank Professor Vera Lúcia Imperatriz-Fonseca for providing the colonies of Schwarziana quadripunctata. Research supported by FAPESP. 


\section{REFERENCES}

Abdalla FC, Cruz-Landim C and Gracioli LF (2005). Tegumentary epithelial glands in the abdomen of virgin and physogastric queens of the stingless bee Scaptotrigona postica Latreille (Meliponini: Trigonina). Neotrop. Entomol. 34: 41-45.

Camargo JMF (1974). Notas sobre a morfologia e biologia de Plebeia (Schwarziana) quadripunctata quadripunctata (Hymenoptera, Apidae, Meliponinae). Stud. Entomol. 17: 433-470.

Castilho-Hyodo VCC (2001). Rainha ou Operária? Um Ensaio Sobre a Determinação de Castas em Schwarziana quadripunctata (Lepeletier, 1836) (Hymenoptera, Apidae, Meliponini). PhD thesis, Universidade de São Paulo, São Paulo.

Engels W and Imperatriz-Fonseca VL (1990). Caste Development, Reproductive Strategies and Control of Fertility in Honey Bees and Stingless Bees. In: Social Insects: An Evolutionary Approach to Castes and Reproduction (Engels W, ed.). Springer-Verlag, Berlin, 167-230.

Ihering H von (1903). Biologie der stachellosen Honigbienen Brasiliens. Zool. Jahrb. Abt. Syst. Geogr. Biol. der Tiere 19: $179-287$.

Imperatriz-Fonseca VL (1990). Swarming Activity in Schwarziana quadripunctata (Apidae, Meliponinae). In: Social Insects and the Environment. Oxford \& IBH Publ. Co., Bombai, 744-745.

Imperatriz-Fonseca VL and Darakjian P (1993). Notas sobre o comportamento das rainhas virgens de Schwarziana quadripunctata (Apidae, Meliponinae). Cienc. Cult. 45: 912.

Imperatriz-Fonseca VL and Zucchi R (1995). Virgin queens in stingless bee (Apidae, Meliponinae) colonies: a review. Apidologie 26: 231-244.

Imperatriz-Fonseca VL, Cruz-Landim C and Moraes RLMS (1997). Dwarf gynes in Nannotrigona testaceicornis (Apidae, Meliponinae, Trigonini), behaviour, exocrine gland morphology and reproductive status. Apidologie 28: 113-122.

Juliani L (1962). O aprisionamento de rainhas virgens em Trigonini. Bol. Univ. Paraná Zool. 20: 1-11.

Kerr WE, Zucchi R, Nakadaira JT and Butolo JE (1962). Reproduction in the social bees (Hymenoptera, Apidae). J. N. Y. Entomol. Soc. 70: 265-276.

Kleinert AMP and Imperatriz-Fonseca VL (1994). Virgin queen refuges in colonies of Melipona marginata (Apidae, Meliponinae). Rev. Bras. Biol. 54: 247-251.

Michener CD (1946). Notes on the habits of some Panamanian stingless bees (Hymenoptera, Apidae). J. N. Y. Entomol. Soc. 54: 179-197.

Nogueira-Ferreira FH and Soares AEE (1998). Male aggregations and mating flight in Tetragonisca angustula (Hymenoptera, Apidae, Meliponinae). Iheringia Sér. Zool. 84: 141-144.

Nogueira-Ferreira FH, Baio MV, Noll FB, Tidon-Sklorz R, et al. (2000). Morphometric study in Schwarziana quadripunctata with emphasis on virgin queens (Hymenoptera, Apidae, Meliponinae). Sociobiology 35: 99-108.

Ribeiro MF and Alves DA (2001). Size variation in Schwarziana quadripunctata queens (Hymenoptera, Apidae, Meliponini). Rev. Etol. 3: 59-65.

Ribeiro MF, Wenseleers T, Santos Filho PS and Alves DA (2006). Miniature queens in stingless bees: basic facts and evolutionary hypotheses. Apidologie 37: 191-206.

Sakagami SF and Zucchi R (1967). Behavior studies of the stingless bees, with special reference to the oviposition process. VI. Trigona (Tetragona) clavipes. J. Fac. Sci Hokkaido Univ. Ser. 6 Zool. 16: 292-313.

Sommeijer M and de Bruijn LLM (1995). Drone congregations apart from the nest in Melipona favosa. Insectes Soc. 42: 123-127.

Wenseleers T, Ratnieks FL, de Ribeiro F, de Alves A, et al. (2005). Working-class royalty: bees beat the caste system. Biol. Lett. 1: 125-128. 